\title{
KEWENANGAN MAHKAMAH KONSTITUSI REPUBLIK INDONESIA DALAM PEMBENTUKAN NORMA BARU (SUATU KAJIAN TERHADAP PUTUSAN MAHKAMAH KONSTITUSI NOMOR 21/PUU-XII/2014 JO PUTUSAN MAHKAMAH KONSTITUSI NOMOR 46/PUU-XIV/2016)
}

\author{
Elisabet \\ (Mahasiswa Program S1 Fakultas Hukum Universitas Tarumanagara) \\ (E-mail: aurelia.elisabet@gmail.com) \\ Dr. Cut Memi, S.H., M.H. \\ (Corresponding Author) \\ (Dosen Fakultas Hukum Universitas Tarumanagara. Meraih Sarjana Hukum pada Fakultas Hukum \\ Universitas Andalas, Magister Hukum pada Fakultas Hukum Universitas Tarumanagara, Doktor (Dr.) \\ pada Fakultas Hukum Universitas Katolik Parahyangan) \\ (E-mail: cutm@fh.untar.ac.id)
}

\begin{abstract}
One of the authorities of the Constitutional Court governed by the Constitution of the Republic of Indonesia in 1945 was the examining of laws against the contitution or judicial review. Inside the regulations which governing the implementation of this authority, the Constitutional Court only acts as a negative legislator, namely canceling or reinforcing a norm tested by the Petitioner. But in practice, the Constitutional Court has changed its role to become a positive legislator, who is forming a new legal norm, which is the authority of legislators. The Constitutional Court should not be able to form a new legal norm because there is no legal basis which regulate that. But Constitutional Court can form a new legal norm in some urgent circumstances, relating to Human Rights, and preventing legal vacuum. In addition, the establishment of laws by lawmakers that require a long process and time. This is compelling Constitutional Court to make substitute norm before the law was established by the legislators. In the Decision of the Constitutional Court Number 46/PUU-XVI/2016, the Court actually wants to establish a new legal norm, but because the articles in the petitioned have criminal sanctions, and if the Constitutional Court approves the petition, the Constitutional Court has formulated a new criminal act that can only be formed by the lawmaker. Whereas in the Decision of the Constitutional Court Number 21/PUU-XII/2014, the Constitutional Court established a new norm because in the article a quo there were no criminal sanctions.
\end{abstract}

Keywords: The Authority, The Constitutional Court, Negative Legislator, Establishment of New Legal Norms. 


\section{PENDAHULUAN}

\section{A. Latar Belakang}

Sebagai lembaga peradilan negara yang melaksanakan kekuasaan kehakiman, fungsi konstitusional yang dimiliki oleh Mahkamah Konstitusi (selanjutnya akan disingkat menjadi MK) adalah menegakan hukum dan keadilan dengan menjalankan kewenangan yang telah dinyatakan dalam Pasal 24C ayat (1) Undang-Undang Dasar Negara Republik Indonesia Tahun 1945 (selanjutnya akan disingkat menjadi UUD NRI 1945), yaitu menguji undang-undang (selanjutnya akan disingkat menjadi UU) terhadap UUD NRI 1945, mengadili sengketa kewenangan lembaga negara, mengadili pembubaran partai politik, mengadili perselisihan tentang hasil pemilihan umum.

Ketentuan yang mengatur MK dalam melaksanakan kewenangannya terdapat di dalam UU No. 24 Tahun 2003 tentang Mahkamah Konstitusi (selanjutnya akan disingkat menjadi UUMK) dan UU No. 8 Tahun 2011 tentang Perubahan Atas UU tentang Mahkamah Konstitusi (selanjutnya akan disingkat menjadi UUPUUMK). Berdasarkan yang terdapat di dalam penjelasan umum UUMK disebutkan bahwa tugas dan fungsi MK adalah mengadili perkara ketatanegaraan atau perkara konstitusional tertentu untuk menjaga agar konstitusi dijalankan secara bertanggung jawab dan sesuai dengan kehendak rakyat dan cita-cita terhadap pengalaman ketatanegaraan yang disebabkan oleh multitafsir atas konstitusi. ${ }^{1}$

Salah satu kewenangan MK sebagai Court of Law adalah menguji norma di dalam UU terhadap konstitusi secara materil dan formil, namun kewenangan tersebut masih menimbulkan banyak permasalahan dalam isi putusannya dalam beberapa putusan MK masih ada yang saling bertentangan, ultra petita, dan lain-lain. Salah satunya permasalahan dalam isi putusan MK tentang pengujian norma di dalam UU terhadap UUD NRI 1945 adalah pembentukan norma baru.

\footnotetext{
1) A. Mukthie Fadjar, Hukum Konstitusi dan Mahkamah Konstitusi (Jakarta: Sekretariat Jenderal dan Kepaniteraan MK RI, 2006), 119.
} 
Pembentukan norma baru seharusnya dilakukan oleh positive legislator yaitu DPR bersama-sama dengan Presiden, namun dalam putusannya, MK juga pernah melakukan pembentukan norma baru, walaupun posisi MK adalah sebagai negative legislator.

Di dalam UUPUUMK telah mengatur putusan yang dapat diputuskan oleh MK. Pasal 57 ayat (2a) huruf c UUPUUMK menyatakan bahwa, MK tidak memiliki kewenangan untuk membentuk rumusan norma hukum baru sebagai pengganti norma dari undnag-undnag yang bertentangan dengan UUD NRI 1945, hal ini tercermin dalam Putusan MK No. 46/PUU-XIV/2016.

Di dalam permohonan atas perkara Nomor 46/PUU-XIV/2016 Pemohon melakukan pengujian materiil Pasal 284, Pasal 285, dan Pasal 292 Kitab Undang-Undang Hukum Pidana (KUHP). Putusan tersebut dimohonkan agar terciptanya ketahanan keluarga, perlindungan terhadap nilai-nilai agama di Indonesia karena dasar filosofis negara Indonesia adalah agama dan problematika KUHP.

Menurut para Pemohon ketiga pasal yang diajukan untuk diuji merupakan pasal-pasal yang sangat mengancam ketahanan keluarga yang pada akhirnya mengancam ketahanan nasional. Pasal 284 KUHP tentang perzinaan hanya dibatasi oleh salah satu pelakunya dalam ikatan perkawinan, perzinaan di luar ikatan perkawinan masih dianggap hal yang tidak dilarang padahal perzinaan di luar perkawinan merupakan salah satu akibat hancurnya masa depan generasi muda dan menambah masalah keluarga dan masyarakat. Sehingga pemohon dalam pokok permohonannya meminta MK memperluas ruang lingkup dari para pihak yang melakukan zina. Dalam hal Pasal 285 KUHP tentang pemerkosaan yang dibatasi hanya wanita saja sebagai korbannya, padahal korban dari pemerkosaan ternyata bisa juga laki-laki, sesama laki-laki, dewasa, anak-anak, sesama anak-anak, bahkan terhadap manula. Sehingga pemohon dalam pokok permohonannya meminta MK memperluas ruang lingkup korban, tidak hanya wanita saja hal ini dilakukan untuk memberikan perlindungan 
kepada seluruh masyarakat Indonesia. Pemberlakuan Pasal 292 KUHP tidak melindungi kelompok korban orang dewasa dan juga tidak memberi rasa keadilan dan kepastian hukul dalam hal pelakunya adalah orang bukan dewasa. Sehingga pemohon dalam pokok permohonannya meminta MK memperluas ruang lingkup dari pelaku dan korban. Pemohon memohon agar pelaku yang dicakup Pasal 292 KUHP tidak hanya orangdewasa namun juga orang yang belum dewasa dan korban yang dicakup Pasal 292 KUHP tidak hanya orng belum dewasa, namun orang dewasa juga. Jika ditinjau dari sudut keagamaan, agama-agama di Indonesia melarang perzinaan di luar perkawinan (Pasal 284 KUHP), melarang pemerkosaan kepada siapa saja (Pasal 285 KUHP) dan melarang hubungan ke sesama jenis (Pasal 292 KUHP). Ketiga Pasal ini menyebabkan problmatika KUHP karena terjadinya pergeseran nilai-nilai yang meyebabkan kekosongan hukum yang ada di Indonesia perihal kesusilaan. Namun MK di dalam amar putusannya menolak permohonan uji materiil ketiga pasal tersebut, sehingga banyak pihak yang salah memahami putusan tersebut dan menganggap MK telah melegalkan perbuatan zina dan LGBT dalam putusannya. Masyarakat menganggap MK dapat memperluas cakupan norma dalam suatu pasal sehingga diharapkan zina bagi para pihak yang belum memiliki ikatan perkawinan dan LGBT dapat memiliki payung hukum yang menaungi.

Namun, terdapat putusan MK Republik Indonesia yang di dalam putusannya terdapat pembuatan norma baru yaitu Putusan MK No. 21/PUUXII/2014 tentang penetapan tersangka dalam ranah praperadilan. Berdasarkan amar Putusan MK tersebut, MK memperluas ruang lingkup dengan menyatakan bahwa, Pasal 77 huruf a UU Nomor 8 Tahun 1981 tentang Hukum Acara Pidana (selanjutnya disingkat KUHAP) bertentangan dengan UUD NRI 1945 sepanjang tidak dimaknai termasuk penetapan tersangka, penggeledahan, dan penyitaan. Dengan amar putusan ini, maka MK melalui putusan permohonan perkara tersangka korupsi bioremediasi PT Chevron Bachtiar Abdul Fatah 
memperluas ranah Praperadilan yang sebelumnya menyatakan bahwa kewenangan praperadilan menurut Pasal a quo adalah sah atau tidaknya penangkapaan, penahanan, penghentian penyidiikan atau penghentian penuntuttan. Namun, melalui putusan tersebut, Mahkamah Konstitusi memperluas ranah praperadilan, sehingga kewenangan praperadilan juga termasuk sah atau tidaknya penetapan tersangka, penggeledahan dan penyitaan. ${ }^{2}$ Dalam hal ini MK telah membuat norma baru dengan memperluas ranah praperadilan.

Berdasarkan kedua putusan tersebut diatas tentu menimbulkan pertanyan tentang konsistensi Mahkamah Konstitusi dalam Pembuatan Norma baru, hal ini menimbulkan persoalaan tentang kepastian hukum. Sehingga patut dipertanyakan putusan yang mana yang benar (reliable), dari kedua putusan tersebut. Hal ini disebabkan karena kedua putusan tersebut bersumber dari satu lemabaga negara yang sama yaitu Mahkamah Konstitusi.

Berdasarkan dari permasalahan yang telah diuraikan tersebut, maka Penulis merasa tertarik untuk membahas permasalahan inidalam tulisan dengan judul: "Kewenangan Mahkamah Konstitusi Republik Indonesia dalam Pembentukan Norma Hukum Baru (Suatu Kajian terhadap Putusan Mahkamah Konstitusi No. 21/PUU-XII/2014 jo Putusan Mahkamah Konstitusi No. 46/PUU-XIV/2016)".

\section{B. Perumusan Masalah}

Adapun rumusan masalah yang ada dan dikaji dalam penulisan ini dapat dirumuskan sebagai berikut: Bagaimana kewenangan Mahkamah Konstitusi Republik Indonesia dalam pembentukan norma hukum baru berdasarkan Putusan Mahkamah Konstitusi No. 21/PUU-XII/2014 jo Putusan Mahkamah Konstitusi No. 46/PUU-XIV/2016?

\footnotetext{
2) Ranny Virginia Utami, "MK Putuskan Penetapan Tersangka Masuk Objek Praperadilan", https://www.cnnindonesia.com/nasional/20150428163639-12-49799/mk-putuskan-penetapantersangka-masuk-objek-praperadilan, diakses tanggal 12 Desember 2018.
} 


\section{Tujuan dan Kegunaan Penulisan}

1. Tujuan Penelitian

Berdasarkan permasalahan tersebut yang menjadi tujuan penelitian dalam penulisan penelitian ini adalah untuk meneliti mengenai kewenangan Mahkamah Konstitusi Republik Indonesia dalam pembentukan norma hukum baru berdasarkan Putusan MK No. 21/PUUXII/2014 jo Putusan MK No. 46/PUU-XIV/2016

2. Kegunaan Penelitian

a. Manfaat Teoritis

Secara teoritis, hasil dari penelitian ini diharapkan dapat memberikan manfaat bagi perkembangan ilmu hukum khususnya berkaitan mengenai kepastian mengenai putusan MK yang memiliki pembuatan norma baru di dalamnya, sehingga dapat mnjadi referensi bagi yang akan melakukan penelitiian dalam masalah terkait.

b. Manfaat Praktis

Secara praktis, hasil dari penelitian ini diharapkan dapat menjadi masukan untuk Mahkamah Konstitusi sehingga dapat membuat putusan yang lebih harmonis. Dan untuk pihak lain, penelitian ini diharapkan juga dapat membantu dalam penyajiian informasi untuk mengadakan penelitian berikutnya yang serupa dan penelitian ini dapat menjadi sumbangan penelitian.

\section{Metode Penelitian}

Penelitian hukum yang telah digunakan untuk melakukan penelitian ini adalah penelitian hukum normatif. Teknik pengumpulan data yang diterapkan dalam penulisan ini yaitu dengan melakukan studi pustaka (library research) terhadap bahan-bahan hukum, baik bahan hukum primer, bahan hukum sekunder maupun bahan nonhukum. Pendekatan penelitian dilakukan dengan melakukan pendekatan undang-undang (statute approach). Spesifikasi penelitian dalam penelitian ini yaitu dengan penelitian deskriptif analitis. 
Dengan penelitian deskriptif analitis, dapat dideskripsikan dan memberikan data seteliti mungkin mengenai objek yang diteliti. ${ }^{3}$ Teknik analisis yang dipergunakan dalam penelitian ini adalah metode deduktif. Metode deduktif adalah metode pemikiran yang bersumber dari kejadian-kejadian umum untuk memutuskan kaidah khusus.

\section{PEMBAHASAN}

A. Kewenangan Mahkamah Konstitusi dalam Pengujian Undang-Undang Terhadap Undang-Undang Dasar Negara Republik Indonesia 1945 Berdasarkan Peraturan Perundang-Undangan

Sebagaimana telah dikemukakan sebelumnya, kewenangan Mahkamah Konstitusi Republik Indonesia yang diberikan oleh konstitusi negara Indonesia terdapat di dalam Pasal 24C ayat (1) UUD NRI 1945 yaitu menguji UU terhadap UUD NRI 1945, mengadili sengketa kewenangan lembaga negara yang kewenangannya diberikan oleh UUD NRI 1945, mengadili pembubaraan parpol, mengadili perselisiihan tentang hasil pemilu.

Kewenangan MK yang akan dibahas dalam penelitian ini adalah tentang pengujian UU terhadap UUD NRI 1945. Pengujian UU terhadap UUD NRI 1945 oleh MK dapat berupa pengujian UU secara formil dan materiil. Dalam mengangani permohonan pengujian formil berdasarkan Pasal 51A UUPUUMK, pemeriksaan dan putusan yang dilakukan oleh MK didasarkan pada peraturan perundang-undangan yang mengatur tata cara pembentukan peraturan perundang-undangan. Sebagai lembaga yudisial, MK memiliki hukum acara yang biasanya disebut hukum acara MK, Dalam kewenangan ini MK sebagai lembaga yudisial diberi kewenangan untuk megadili sengketa terhadap UU yang bertentangan dengan UUD NRI 1945 atau disebut dengan judicial review.

\footnotetext{
3) Tunjung Herning Sitabuana, "Penyelesaian Masalah Diskriminasi Terhadap Etnis Cina (Studi Tentang Perkembangan Politik Hukum di Bidang Kewarganegaraan Republik Indonesia)", (Ringkasan Disertasi Doktor, Universitas Diponegoro, 2011), 86.
} 
Mengenai hukum acara pengujian UU di MK diatur di dalam Pasal 50 sampai Pasal 60 UUMK dan UUPUUMK serta Peraturan Mahkamah Konstitusi Nomor 06/PMK/2005 tentang Pedoman Beracara dalam Perkara Pengujian UndangUndnag (Pedoman PUU).

Di dalam Pasal 50A dalam UU Perubahan atas UUMK, menyatakan bahwa MK dalam menguji UU terhadap UUD NRI 1945 tidak UU lain sebagai dasar. Sehingga, MK menegaskan bahwa MK hanya dapat melakukan pengujian UU yang sifatnya vertikal.

Berdasarkan Pasal 51A ayat (2) UU Perubahan atas UUMK, uraian yang menjadi dasar permohonan dalam perkara pengujian UU meliputi:

1. Kewenangan MK dalam melakukaan pengujiian;

2. Kedudukan hukum pemohon dapat berupa kerugian faktual ataupun kerugian potensial, yang berisi uraian tentang hak dan/atau kewenangan konstitusi pemohon yang dianggap dirugikan dengan berlakunya UU yang dimohonkan untuk dilakukan pengujian, kerugian oleh pemohon ini

3. Alasan permohonan pengujian.

Selanjutnya dalam hal permohonan yang pengujian formil maka berdasarkan Pasal 51A ayat (3) UU Perubahan atas UUMK hal yang dimohonkan untuk diputus meliputi:

a. Mengabulkan Permohonan Pemohon;

b. Menyatakan bahwa pembentukan UU dimaksud tidak memenuhi ketentuan pembentukan UU berdasarkan UUD NRI 1945;

c. Menyatakan UU tersebut tidak mempunyai kekuatan hukum mengikat. Apabila permohonan pengujian yang dimohonkan oleh Pemohon adalah pengujian materiil, maka berdasarkan Pasal 51A ayat (4) UU Perubahan atas UUMK hal yang dimohonkan untuk diputus dalam permohonan meliputi:

a. Mengabulkan permohonan pemohon;

b. Menyatakan bahwa materi muatan ayat, pasal dan/atau bagian dari UU dimaksud bertentangan dengan UUD NRI 1945; dan 
c. Menyatakan bahwa materi muatan ayat, pasal, dan/atau bagian dari UU dimaksud tidak mempunyai kekuatan hukum mengikat.

Setelah berkas permohonan lengkap, maka permohononan dicatat dalam Buku Registrasi Perkara. Berdasarkan Pasal 58 UUMK, UU yang diuji dan belum ada putusannya tetap berlaku, sebelum ada putusan yang menyatakn bahwa UU tersebut bertentangan dengan UUD NRI 1945.

Pasal 56 UUMK mengatur 3 (tiga) jenis amar putusan yaitu, putusan yang menyatakan permohonan tidak dapat diterima, putusan yang menyatakan permohonan dikabulkan dan putusan yang menyatakan permohonan ditolak. Di dalam putusan MK, Menurut Pasal 57 ayat (2a) UU Perubahan atas UUMK, putusan MK tidak memuat:

a. Amar selain yang ditentukan dalam UUMK dan perubahannya

b. Perintah kepada pembuat UU; dan

c. Rumusan norma sebagai pengganti norma dari UU yang dinyatakan bertentangan dengan UUD NRI 1945.

Setelah dikeluarkan putusan MK mengenai pengujian UU terhadap UUD NRI 1945, putusan tersebut harus disampaikan kepada DPR, DPD, Presiden dan MA. Jika diperlukan perubahan terhadap UU yang telah diuji, pembentuk UU harus segera menindaklanjuti putusan tersebut sesuai dengan peraturan perundang-undnagan.

\section{B. Pembentukan Norma Baru oleh Mahkamah Konstitusi}

Dalam perkembangannya, amar di dalam putusan MK tidak hanya diterima, ditolak atau dikabulkan, namun dalam praktiknya dalam amar putusan MK juga terdapat, amar putusan konstitusional bersyarat (conditionally constitution) dan amar putusan tidak konstitusional bersyarat (conditionally 
inconstitution), penundaan keberlakuan putusan dan perumusan norma dalam putusan. $^{4}$

Putusan konstitusional bersyarat atau conditionally constitution merupakan putusan yang menyatakan bahwa suatu ketentuan UU tidak bertentangan dengan UUD NRI 1945 dengan memberikan persyaratan pemaknaan. Putusan inkonstitusional bersyarat atau conditionally inconstitution, jenis putusan ini kebalikan dari putusan konstitusional bersyarat, putusan ini menyatakan bahwa suatu ketentuan UU dinyatakan bertentangan dengan UUD NRI 1945 jika persyaratan yang diberikan MK tidak terpenuhi. Selanjutnya putusan yang pemberlakuannya ditunda atau limited constitutional, putusan ini menoleransi penundaan berlakunya aturan yang sebenarnya bertentangan dengan UUD NRI 1945 hingga batas waktu tertentu. Jenis putusan yang selanjutnya adalah model putusan yang merumuskan norma baru yaitu amar putusan yang di dalam nya terdapat rumusan baru atas norma yang diuji oleh Mahkamah Konstitusi. $^{5}$

Keempat jenis amar putusan ini tidak diatur di dalam UUMK, UUPUUMK dan Pedoman PUU. Amar putusan konstitusional bersyarat, inkonstitusional bersyarat dan putusan yang merumuskan norma baru menimbulkan kekeliruan bagi masyarakat terhadap peran Mahkamah Konstitusi yang seharusnya adalah negative legislator berubah menjadi positif legislator. Juru Bicara MK, Fajar Laksono, mengemukakan, bahwa amar putusan MK secara normatif, amar putusan MK ada tiga yaitu dikabulkan, ditolak dan tidak dapat diterima, namun dalam praktiknya ketiga jenis amar putusan tersebut belum cukup memberikan rasa keadilan dan kepastian bagi masyarakat, karena

4) Tim Penyusun, Hukum Acara Mahkamah Konstitusi, (Jakarta: Sekretariat Jenderal dan Kepaniteraan Mahkamah Konstitusi, 2010), 205-206.

5) Ali Marwan Hsb, Konsep Judicial Reviewdalam Pelembagaannya di Berbagai Negara, (Malang: Setara Press, 2017), 116-117. 
itu sejak tahun 2004 lahirlah putusan bersyarat demi memberi rasa keadilan, kepastian dan mencegah kekeosongan hukum. ${ }^{6}$

Di dalam Pasal 57 ayat (2a) huruf c menyatakan bahwa dalam putusan pengujian undang-undang terhadap UUD NRI 1945, bukanlah posisi MK untk membentuk rumusan norma sebagai pengganti norm dari undnag-undnag yang dinyatakan bertentangan dengan UUD NRI 1945. Pasal ini bertujuan untuk melarang MK melakukan ultra petita dalam putusannya. Putusan bersyarat dan putusan yang merumuskan norma baru telah melebihi aturan putusan yang boleh dikeluarkan oleh MK dalam Pasal 56 UUMK. Membentuk norma hukum adalah kewenangan dari pembentuk undnag-undnag, MK seharusnya hanya membatalkan atau menegaskan suatu norma hukum. Ketika norma hukum yang diuji tidak selaras dengan UUD NRI 1945, maka seharusnya merupakan tugas dari pembentuk undnang-undang untuk memperbaikki atau merevisi produk hukum yang sudah dibuat olehnya.

MK sebagai negative legislator seharusnya hanya dapat membatalkan dan mempertegas undang-undang yang diujikan. Sedangkan tindak lanjut atas Putusan MK dalam mempertegas atau membatalkan undang-undang seharusnya dilaksanakan oleh pembentuk Undang-Undang, hal ini diatur dalam Pasal 10 ayat (2) Undang-Undang Nomor 12 Tahun 2011 tentang Pembentukan Peraturan Perundang-Undangan. Dimyati Natakusumah berpendapat bahwa larangan ultra petita dalam putusan MK dimaksudkan agar MK tidak membentuk norma baru dalam putusannya. Pendapat ini juga menegaskan bahwa MK seharusnya hanya membatalkan dan menegaskan norma hukum yang diuji saja, dan pembentukan norma baru seharusnya dilakukan oleh pembentuk undang-undnag. Pasal 57 UUPUUMK juga melarang MK untuk

6) Aida Mardatillah, "Mengurai Problem Putusan Konstitusional Bersyarat dan Inkonstitusional Bersayarat", https://www.hukumonline.com/berita/baca/lt5b59297251caa/mengurai-problem-putusankonstitusional-bersyarat-dan-inkonstitusional-bersyarat, diakses pada tanggal 12 Desember 2018. 
membentuk norma baru dalam putusannya karena merupakan kewenangan yang diberikan oleh UUD NRI 1945 secara langsung kepada Pemerintah dan DPR. ${ }^{7}$

Pembahasan jurnal ini, mengkaji 2 putusan MK sebagai perbandingan dalam penulisan ini yaitu Putusan MK Nomor 21/PUU-XII/2014 dan Putusan MK Nomor 46/PUU-XIV/2016. Dalam Putusan MK Nomor 21/PUU-XII/2014 yang merupakan putusan conditionally inconstitutional atau putusan inkonstitusional bersyarat, kewenangan praperadilan yang diatur dalam Pasal 77 huruf a KUHAP yang seharusnya sebatas memeriksa dan memutus sah atau tidaknya penangkapan, penahanan, penghentian penyidikan atau penghentian penuntutan, diperluas oleh Putusan MK Nomor 21/PUU-XII/2014 termasuk penetapan tersangka, penggeledahan dan penyitaan.

Dalam putusan tersebut, MK memperluas kewenangan praperadilan dan membentuk norma baru. Hakim Mahkamah Konstitusi, Aswanto berpandangan bahwa memasukkan penetapan tersangka sebagai objek praperadilan bukanlah persoalan penafsiran, sebab tidak ada kata atau frasa di dalam Pasal 77 huruf a KUHAP yang dapat dimaknai sebagai penetapan tersangka atau termasuk penetapan tersangka, ketentuan dalam Pasal 77 huruf a KUHAP sudah sangat jelas mengatur ketentuan hal-hal yang dapat diujikan di forum praperadilan. ${ }^{8}$

Kemudian Hakim MK Muhammad Alim berpandangan bahwa penetapan tersangka bukan kewenangan dari praperadilan jika prosedur yang dilaksanakan untuk menetapkan tersangka dilakukan dengan baik oleh penyidik, namun jika terjadi penyalahgunaan wewenang, maka hal itu bukan kewenangan dari MK, sebab hal tersebut merupakan penerapan hukum, pengujian terhadap penerapan hukum bukan kewenangan dari MK.

\footnotetext{
Ash, "Membentuk Norma Bukan Kewenangan MK", https://www.hukumonline.com/berita/baca/lt4e7362761a672/membentuk-norma-bukan-kewenanganmk, diakses pada tanggal 12 Desember 2018.

8) Agus Sabani, “MK 'Rombak'Bukti Permulaan dan Objek Praperadilan”, https://www.hukumonline.com/berita/baca/lt553f5575acd85/mk-rombak-bukti-permulaan-dan-objekpraperadilan, diakses pada tanggal 10 Desember 2018.
} 
Dalam Putusan MK Nomor 21/PUU-XII/2014 terdapat 1 alasan berbeda Hakim Konstitusi Patrialis Akbar, walaupun beliau setuju dan mendukung putusan MK dalam perkara Putusan Nomor 21/PUU-XII/2014, Hakim Konstitusi Patrialis Akbar mengatakan akan lebih tepat jika perkara ini diserahkan kepada pembentuk undang-undang untuk menentukan pilihan objekobjek praperadilan asal sejalan dan tidak bertentangan dengan UUD NRI 1945 dengan memperhatikan sungguh-sungguh pertimbangan hukum MK a quo.

Di dalam amar Putusan Mahkamah Konstitusi Nomor 46/PUU-XIV/2016, MK menolak permohonan pengujian Pasal 284 KUHP, Pasal 285 KUHP dan Pasal 292 KUHP. Dalam pokok permohonannya, pemohon meminta kepada Majelis Hakim Konstitusi untuk memperluas ruang lingkup Pasal 284 KUHP, Pasal 285 KUHP dan Pasal 292 KUHP. Pemohon meminta agar Pasal 284 KUHP tidak membatasi pelaku yang melakukan perbuatan zina hanya jika salah seorang telah memiliki ikatan perkawinan.

Di dalam Pasal 285 KUHP, pemohon memohon kepada Majelis Hakim Mahkamah Konstitusi untuk memperluas Pasal 285 KUHP sehingga korban pemerkosaan yang dicakup di dalam Pasal 285 KUHP tidak hanya wanita saja, namun termasuk laki-laki, sesama laki-laki, dewasa, anak-anak, sesama anakanak, bahkan terhadap manula.

Di dalam Pasal 292 KUHP, pemohon meminta kepada Majelis Hakim Konstitusi untuk memperluas cakupan pelaku dan korban dalam Pasal a quo, sehingga pelaku yang dicakup dalam perbuatan percabulan di Pasal 292 KUHP tidak hanya orang dewasa saja, namun anak-anak juga dapat menjadi pelaku. Begitu juga dengan korban percabulan yang dicakup Pasal 292 KUHP tidak hanya anak-anak saja, namun pemohon meminta Majelis Hakim Konstitusi untuk mencakup orang yang sudah dewasa juga dapat menjadi korban percabulan dalam Pasal 292 KUHP.

Dalam pertimbangan perkara Putusan Nomor 46/PUU-XIV/2016, MK menyatakan bahwa MK tidak berwenang untuk membetuk tindak pidana baru, 
hal itu hanya kewenangan pembentuk undang-undang dalam hal ini DPR bersama-sama dengan Presiden. Pertimbangan MK, dalam menghilangkan frasa tertentu dan/atau menambahkan pemaknaan baru terhadap suatu norma hukum pidana, hal itu dapat mengubah sifat melawan hukum perbuatan tersebut tanpa melakukan perubahan atau penyesuaian dalam ancaman pidananya, sehingga hal itu tidak dapat diterima oleh penalaran hukum dalam merancang suatu norma hukum pidana karena hal itu melekat pada jenis atau kualifikasi perbuatan yang dapat dipidana atau tindak pidana yang bersangkutan.

Kemudian dalam hukum pidana, terminologi "undang-undang" yang terkandung dalam empat makna asas legalitas adalah merujuk pada pengertian undang-undang dalam arti sesungguhnya yaitu produk hukum tertulis yang dibuat oleh pembentuk undang-undang dalam hal ini DPR bersama-sama dengan Presiden, sehingga produk hukum yang lahir dari kebijakan pidana atau politik hukum pidana harus berasal dari pembentuk undang-undang.

Selanjutnya walaupun putusan MK memiliki daya ikat yang sama dengan undang-undang dan sering menyatakan suatu norma conditionally constitutional ataupun concditionally inconstitutional, namun dalam konteks pemahaman akan kedudukan MK sebagai negative legislator, MK tidak boleh memasuki wilayah kebijakan pidana atau politik hukum pidana.

Dalam pertimbangannya terhadap Pasal 284 KUHP, MK berpandangan bahwa persoalan kurang lengkapnya cakupan dari Pasal a quo berbeda dengan persoalan inkonstitusionalitas sehingga merupakan tugas dari pembentuk undang-undang untuk menyempurnakan atau melengkapi kekurangan itu setelah memperhatikan perkembangan hukum dalam masyarakat, selain itu kekosongan hukum dalam pengertian zina seharusnya diisi melalui proses legislasi oleh pembentuk undang-undang. Dalam Pasal 285 KUHP, MK berpandangan bahwa kekosongan hukum terjadi karena kebijakan kriminalisasi pembentuk undang-undang belum menetapkan atau mengatur perkosaan oleh perempuan terhadap laki-laki, sehingga hal ini juga merupakan tugas dari 
pembentuk undang-undang. Dalam Pasal 292 KUHP, MK berpandangan bahwa seharusnya upaya yang ditempuh dalam mengikuti perkembangan masyarakat yaitu mengajukan usul dan mendorong perbahan undang-undang kepada pembentuk undang-undnag untuk menjadikan perbuatan cabul terhadap orang dewasa atau sesama anak-anak sebagai tindak pidana. Terakhir dalam pertimbangannya MK hanya menyatakan bahwa norma pasal-pasal dalam KUHP yang dimohonkan oleh Pemohon tidak bertentangan dengan UUD NRI 1945, perlu atau tidaknya dilengkapi, merupakan kewenangan pembentuk undang-undang melalui kebijakan pidana yang merupakan bagian dari politik hukum pidana.

Seluruh norma hukum di dalam peraturan perundang-undangan dibawah UUD NRI 1945 harus merujuk ke norma dasar atau UUD NRI 1945. Jika peraturan perundang-undangan yang hierarki nya lebih rendah diduga bertentangan bertentangan dengan peraturan perundang-undangan yang lebih tinggi, maka harus dilakukan pengujian peraturan perundang-undangan atau judicial review. Dalam Pasal 9 UU Nomor 12 Tahun 2011 tentang Pembentukan Peraturan Perundang-Undangan, lembaga negara yang berwenang dalam melakukan judicial review adalah Mahkamah Agung dan Mahkamah Konstitusi. Di dalam Pasal 9 ayat (1) UU Pembentukan Peraturan Perundang-Undangan, Mahkamah Agung berwenang menguji peraturan perundang-undangan dibawah undang-undang terhadap undang-undang. Sedangkan di dalam Pasal 9 ayat (2) UU Pembentukan Peraturan PerundangUndangan, Mahkamah Konstitusi berwenang menguji undang-undang terhadap UUD NRI 1945.

Dalam teori Penal Policy, terdapat tiga tahap proses operasionalisasi kebijakan hukum pidana dengan sarana pidana yaitu tahap formulasi yang merupakan kebijakan legislative, dalam tahap ini pembentuk undang-undang membentuk kebijakan atau norma hukum yang akan dilaksanakan. Tahap aplikasi yang merupakan kebijakan yudikatif yaitu badan peradilan yang 
mengawasi pelaksanaan dari kebijakan hukum atau normah hukum yang telah dibentuk oleh pembentuk undang-undang. Takhap eksekusi yang merupakan kebijakan eksekutif. ${ }^{9}$ Dalam tahapan ini, Mahkamah Konstitusi sebagai lembaga yudikatif berada dalam tahapan aplikasi yang merupakan kekuasaan dalam hal menerapkan hukum pidana oleh aparat penegak hukum atau pengadilan. Kewenangan dalam hal menetapkan atau merumuskan perbuatan apa yang dapat dipidana dan berorientasi pada permasalahan pokok dalam hukum pidana meliputi perbuatan yang bersifat melawan hukum, kesalahan atau pertanggungjawaban pidana dan sanksi apa yang dikenakan merupakan kewenangan pembuat undang-undang dalam hal ini DPR bersama-sama dengan Presiden. Sehingga dalam hal ini Putusan MK Nomor 46/PUU-XIV/2016 sudah sesuai dengan teori ini, namun dalam Putusan MK Nomor 21/PUU-XII/2014 MK telah melebihi kewenangannya dan melanggar teori penal policy atau teori kebijakan hukum pidana, karena MK membentuk norma baru dalam ranah hukum acara pidana.

Di dalam UUD NRI 1945, telah diatur pembagian kewenangan untuk organ-organ pemerintahan, kewenangan ini disebut sebagai kewenangan atribusi. Pasal 20 UUD NRI 1945 telah mengatur kewenangan atribusi dalam pembentukan undang-undang yang akan dilaksanakan oleh Dewan Perwakilan Rakyat, kewenangan atribusi yang diberikan kepada MK terdapar di dalam Pasal Pasal 24C ayat (1) UUD NRI 1945 yaitu menguji UU terhadap UUD NRI 1945, mengadili sengketa kewenangan lembaga negara yang kewenangannya diberikan oleh UUD NRI 1945, mengadili pembubaran partai politik mengadili perselisihan tentang hasil pemilihan umum. Sehingga kewenangan yang diberikan oleh UUD NRI 1945 dalam membentuk norma hukum baru bukan kewenangan MK namun kewenangan pembentuk undang-undang atau DPR bersama-sama dengan Presiden.

\footnotetext{
${ }^{9}$ ) Barda Nawawi Arif, Masalah Penegakan Hukum dan Kebijakan Hukum Pidana dalam Penanggulangan Kejahatan, (Jakarta: Kencana Media Group, 2007), 78-79.
} 
Judicial review atau pengujian peraturan perundang-undangan memiliki arti yang beragam di berbagai negara, di Indonesia dalam UUMK dan UUPUUMK, judicial review yang dilaksanakan oleh Mahkamah Konstitusi seharusnya hanya sebatas menguji konstitutionalitas prosedur pembuatan undang-undang dan materi muatan pasal, ayat dan/atau bagian-bagian lain yang terdapat di dalam undang-undang. Sehingga, MK telah melebihi kapasitasnya dalam pelaksanaan judicial review jika membentuk norma hukum baru dalam putusannya.

Dibentuknya Mahkamah Konstitusi adalah untuk mengawal konstitusi dengan menjaga undang-undang agar konsisten dan tidak bertentangan dengan UUD NRI 1945. Secara normatif, MK diberi ruang kewenngan yang terbatas sebagai negative legislator. Ketentuan MK sebagai negative legislator didukung dalam Pasal 56 dan 57 UUMK jo UU Perubahan atas UUMK. Dalam Pasal 56 UUMK, terdapat 3 (tiga) jenis putusan yang dapat dikeluarkan oleh MK yaitu dikabulkan, ditolak dan tidak dapat diterima. Jika putusan dikabulkan, dalam Pasal 57 ayat (1) dan ayat (2) UUMK jo UU Perubahan atas UUMK, undang-undang yang diujikan tersebut dinyatakan tidak memiliki kekuatan hukum mengikat. Sedangkan di dalam Pasal 57 ayat (2a) UU Perubahan atas UUMK, MK dilarang mengeluarkan amar putusan selain yang ditentukan dalam UUMK dan perubahannya, perintah kepada pembuat undangundang dan rumusan norma sebagai pengganti norma dari undang-undnag yang dinyatakan bertentangan dengan Undang-Undang Dasar Negara Republik Indonesia Tahun 1945. Dalam konteks inilah MK seharusnya memerankan diri sebagai negative legislator atau pembatal norma. Namun dalam praktiknya, MK dalam putusannya membentuk norma baru. Sebagai negative legislator, MK seharusnya hanya membatalkan norma yang ada di dalam suatu undangundang jika bertentangan dengan UUD NRI 1945, MK seharusnya tidak dapat membentuk norma hukum baru yang sesungguhnya menjadi kewenangan pembentuk undang-undang. 
Menurut Ibu Maria Farida Indrati Soeprapto, Kewenangan membuat norma hukum baru sebenarnya merupakan ranah legislatif dan MK hanya berperan sebagai negative legislator, namun dalam keadaan tertentu yang mendesak dan bertentangan dengan hak asasi manusia, maka MK harus memutuskan suatu perkara dengan membentuk norma hukum baru dan berubah menjadi positive legislator. Jika MK hanya mengabulkan dari sisi permohonan saja, maka akan terjadi kekosongan hukum dan tidak terpenuhinya hak asasi manusia.

Menurut BapakMaruarar Siahaan, Hakim Konstitusi periode tahun 20032006, kewenangan untuk membentuk norma hukum seharusnya dilakukan oleh pembentuk undang-undang. Namun jika hanya mengandalkan pembentuk undang-undang, maka pelaksanaan Hak Asasi Manusia (HAM) warga negara akan tertunda, karena proses pelaksanaan pembuatan undang-undang yang tidak secepat putusan. Sehingga, jika muncul suatu pengujian undang-undang yang menunda dilaksanakannya HAM dan MK hanya berperan sebagai negative legislator yaitu menyatakan suatu norma tidak berlaku lagi tanpa menambahkan norma yang mengatur, hal ini akan menimbulkan pelanggaran HAM dan kekosongan hukum. Oleh karena itu, untuk mencegah terjadinya pelanggaran HAM dan kekosongan hukum, maka MK merasa perlu untuk membentuk norma hukum baru ketika membatalkan suatu materi muatan dalam undangundang. Sehingga dalam keadaan tertentu yang sangat mendesak, MK bergerak meluruskan norma. Sehingga ketika MK menyatakan suatu pasal dalam permasalahan tersebut batal, maka MK membentuk norma yang seharusnya dibentuk oleh pembentuk undang-undang.

Menurut Muhidin, Panitera Muda II Mahkamah Konstitusi RI, MK tidak membuat norma namun menafsirkan norma, MK membentuk rumusan penafsiran dalam rangka mempertegas norma yang diuji. Kewenangan pembentukan norma hukum berada di pembentuk undang-undang, namun dalam keadaan tertentu MK harus mempertimbangkan untuk menafsirkan 
norma. Walaupun MK tidak berwenang membentuk norma hukum baru dari penafsirannya, namun jika MK hanya berperan sebagai negative legislator, maka akan banyak hak asasi manusia yang tercederai. Parameter atau batasan keadaan untuk MK dalam membentuk norma baru adalah hanya terhadap keadaan yang extraordinary yaitu keadaan yang harus benar-benar mendesak perlindungan hak-hak konstitusional warga negara. Dalam putusan MK Nomor 21/PUU-XII/2014, perluasan makna yang dilakukan oleh MK adalah rangka dalam melindungi dan menegakan atau mengawal hak asasi manusia. Walaupun sebenarnya perluasan kewenangan praperadilan seharusnya diubah oleh pembuat undang-undang dan berada di dalam undang-undang, namun proses pembuatan undang-undang membutuhkan waktu yang lama. Sedangkan di dalam Putusan MK Nomor 46/PUU-XIV/2016, perluasan makna zina seharusnya dibentuk oleh pembuat undang-undang, dengan mempertimbangkan RUU KUHP yang sedang dibahas oleh DPR sebagai pembentuk undangundang.

Menurut Ahmad Redi, Dosen Fakultas Hukum Universitas Tarumanagara, kewenangan membentuk norma hukum baru merupakan kewenangan pembentuk undang-undang. Dalam konteks perkembangan pemikiran, secara original intent dari UUD NRI 1945, MK dalam melakukan pengujian UU terhadap UUD NRI 1945 hanya sebatas sesuai atau tidak sesuai saja, hanya sebagai negative legislator saja. Namun dalam praktiknya, MK berperan juga sebagai positive legislator hal ini merupakan hal yang sah jika dalam konteks menencegah terjadinya kekosongan hukum dan menghindari ketidakpastian hukum, namun hal tersebut menjadi tidak sesuai dengan semangat pembentukan MK. Seharusnya ketika MK memutuskan suatu norma dibatalkan, DPR seharusnya segera bergerak membuat norma baru agar sesuai dengan konstitusi, namun pada faktanya tidak demikian.

Berdasarkan wawancara yang Penulis lakukan, para ahli berpendapat bahwa kewenangan dalam membentuk UU merupakan kewenangan dari 
pembentuk undang-undang, hal ini juga menjadi kewenangan atribusi untuk DPR dari UUD NRI 1945 sebagai pemegang kekuasaan membentuk undangundang menurut Pasal 20 ayat (1) UUD NRI 1945. Namun Mahkamah Konstitusi sebagai pengawal konstitusi, dalam menjalankan kewenangannya yaitu melakukan pengujian undang-undang atau judicial review tidak dapat hanya memberikan putusan dikabulkan, ditolak atau tidak dapat diterima. Hal ini dikarenakan jika putusan Mahkamah Konstitusi hanya mengabulkan permohonan pemohon, akan terjadi kekosongan hukum. Selain itu, dalam keadaan yang mendesak dan berkaitan dengan Hak Asasi Manusia, Mahkamah Konstitusi dapat membentuk norma baru dengan pertimbangan bahwa Hak Asasi Manusia merupakan salah satu materi muatan di dalam UUD NRI 1945.

Penulis sependapat dengan para narasumber karena sebagai pengawal konstitusi, MK harus menegakan konstitusi dalam hal ini termasuk juga HAM, sebagai salah satu materi muatan dari konstitusi. Selain itu, pembentukan undang-undang oleh pembentuk undang-undang yaitu DPR bersama-sama dengan Presiden yang membutuhkan proses dan waktu lama dapat mencederai hak asasi manusia, sehingga dengan pembentukan norma baru sementara oleh Mahkamah Konstitusi dapat mencegah terjadinya pelanggaran hak asasi manusia.

\section{PENUTUP}

\section{A. Kesimpulan}

Secara normatif, kewenangan dalam membentuk norma hukum merupakan kewenangan dari pembentuk undang-undang, hal ini juga menjadi kewenangan atribusi untuk DPR dari UUD NRI 1945 sebagai pemegang kekuasaan membentuk undang-undang. Tidak ada dasar hukum yang menyatakan bahwa Mahkamah Konstitusi dapat membentuk norma hukum baru, namun dalam keadaan yang mendesak dan berkaitan dengan Hak Asasi Manusia, MK dapat membentuk norma hukum baru. Pembentukan norma 
hukum baru oleh MK bertujuan untuk mencegah kekosongan hukum jika MK telah membatalkan suatu materi muatan yang bertentangan dengan konstitusi. Selain itu, pembentukkan undang-undang yang membutuhkan proses dan waktu tidak sebentar, maka memaksa adanya pembentukan norma hukum pengganti yang dibentuk oleh MK sebelum undang-undang selesai dibentuk oleh pembentuk undang-undnag.

Di dalam Putusan Mahkamah Konstitusi Nomor 46/PUU-XVI/2016, sebenarnya MK ingin membentuk norma hukum baru, namun karena pasalpasal a quo yang dimohonkan memiliki sanksi pidana, dan jika MK mengabulkan permohonan tersebut MK telah merumuskan norma hukum baru yang merupakan kewenangan pembentuk undang-undang. Sedangkan di dalam Putusan Mahkamah Konstitusi Nomor 21/PUU-XII/2014, MK membentuk norma baru karena pada pasal a quo tidak terdapat sanksi pidana.

\section{B. Saran}

Bertitik tolah dari pemabhasan dan kesimpulan diatas, maka beberapa saran yang dapat diberikan adalah:

1. Bagi Pembentuk Undang-Undang agar mempertimbangkan pembentukan dasar hukum berupa batasan-batasan yang jelas bagi Mahkamah Konstitusi untuk membentuk norma hukum baru dalam putusannya dan batasan pemberlakuan putusan MK yang terdapat norma hukum baru di dalamnya. Selain itu, diharapkan pembentuk undang-undang lebih sigap dalam menanggapi putusan MK yang mengabulkan perkara, sehingga pada nantinya, MK tidak perlu lagi berperan sebagai positive legislator.

2. Bagi Hakim Mahkamah Konstitusi, perlu dipertimbangkan semangat pembentukan MK adalah sebagai negative legislator, sehingga diharapkan MK dapat mengurangi intervensi dalam pembentukan norma hukum yang merupakan kewenangan pembentuk undang-undang.

3. Bagi Masyarakat, diperlukan meningkatkan kesadaran bahwa yang memiliki kewenangan untuk membentuk undang-undang adalah DPR 
bersama-sama dengan Presiden, dan kewenangan MK sebagai negative legislator hanya membatalkan dan mempertegas norma saja. Sehingga ketika MK menolak sebuah permohonan, hal ini disebabkan karena MK tidak memiliki dasar hukum untuk mengadili perkara tersebut (Contoh: Putusan Nomor 46/PUU-XIV/2016) 


\section{DAFTAR PUSTAKA}

\section{A. Buku}

Arif, Barda Nawawi. Masalah Penegakan Hukum dan Kebijakan Hukum Pidana dalam Penanggulangan Kejahatan. Jakarta: Kencana Media Group, 2007.

Fadjar, A. Mukthie. Hukum Konstitusi dan Mahkamah Konstitusi. Jakarta: Sekretariat Jenderal dan Kepaniteraan MK RI, 2006.

Hsb, Ali Marwan. Konsep Judicial Reviewdalam Pelembagaannya di Berbagai Negara. Malang: Setara Press, 2017.

Penyusun, Tim. Hukum Acara Mahkamah Konstitus. Jakarta: Sekretariat Jenderal dan Kepaniteraan Mahkamah Konstitusi, 2010.

\section{B. Kutipan Makalah/Paper/Orasi Ilmiah}

Sitabuana, Tunjung Herning. "Penyelesaian Masalah Diskriminasi Terhadap Etnis Cina (Studi Tentang Perkembangan Politik Hukum di Bidang Kewarganegaraan Republik Indonesia)". Ringkasan Disertasi Doktor, Universitas Diponegoro, 2011. hal. 86.

\section{Website}

Ash. "Membentuk Norma Bukan Kewenangan MK". https://www.hukumonline.com/berita/baca/lt4e7362761a672/membentuknorma-bukan-kewenangan-mk. diakses pada tanggal 10 Desember 2018.

Mardatillah, Aida. "Mengurai Problem Putusan Konstitusional Bersyarat dan Inkonstitusional Bersayarat". https://www.hukumonline.com/berita/baca/lt5b59297251caa/menguraiproblem-putusan-konstitusional-bersyarat-dan-inkonstitusional-bersyarat. diakses pada tanggal 10 Desember 2018.

Sabani, Agus. "MK 'Rombak'Bukti Permulaan dan Objek Praperadilan". https://www.hukumonline.com/berita/baca/lt553f5575acd85/mk-rombakbukti-permulaan-dan-objek-praperadilan. diakses pada tanggal 10 Desember 2018.

Utami, Ranny Virginia. "MK Putuskan Penetapan Tersangka Masuk Objek Praperadilan". https://www.cnnindonesia.com/nasional/20150428163639-1249799/mk-putuskan-penetapan-tersangka-masuk-objek-praperadilan. Diakses pada tanggal 12 Desember 2018. 